\title{
Size as indicator of origin of salmon lice Lepeophtheirus salmonis (Copepoda: Caligidae)
}

\author{
Nordhagen, J.R. ${ }^{1}$, P.A. Heuch ${ }^{2 *}$ \& T.A. Schram ${ }^{1}$ \\ ${ }^{1}$ Department of Biology, University of Oslo, P.O. Box 1064 Blindern, 0316 Oslo, Norway, ${ }^{2}$ Fish Health \\ Section, National Veterinary Institute, P.O. Box 8156 Dep., 0033 Oslo, Norway * Corresponding author
}

Key words: Salmon lice, Lepeophtheirus salmonis, origin, size, phenotypic plasticity

\begin{abstract}
Salmon lice Lepeophtheirus salmonis (Kroyer, 1837) from farmed Atlantic salmon have been implicated in the drastic sea trout and salmon stock declines found in Ireland and Norway. Can salmon lice from farmed and wild fish be distinguished? The hypothesis has been advanced that the treatment of salmon infested with salmon lice with organophosphate pesticides has resulted in the evolution of early maturing, smaller female lice, which are favoured because they have the chance to reproduce before treatment. Salmon lice on wild fish have been reported to be larger and have more eggs in their egg strings (sacks) than lice on farmed fish. The question is whether the size differences between the lice are genetically fixed or an expression of phenotypic plasticity. In this study, lice from wild and farmed fish were collected and measured, and it was found that the former were significantly larger. When larvae from these two sources were raised on salmon at the same temperature, they had the same growth rate and morphology. Larvae from the wild lice were raised at $8.7^{\circ} \mathrm{C}$ and $12.2^{\circ} \mathrm{C}$, and attained a significantly larger size at the lower temperature. These results suggest that the salmon louse size is plastic and consequently a poor indicator of salmon louse origin.
\end{abstract}

\section{Contents}

Introduction
Materials and methods
Sampling
Experimental infection of salmon
Equal temperature experiment
Temperature effect experiment
Statistics
Results
Measurements of sampled lice and egg strings
Size and development of progeny of lice from
farmed and wild salmon
Size of lice reared at different temperatures
Discussion
Sampled lice and egg strings

Temperature effects

Genetic aspects

Conclusions

Acknowledgèments

References

\section{Introduction}

The salmon louse, L. salmonis is the cause of one of the most important diseases in European salmon farming. Since 1990 an increasing number of reports have also documented the debilitating effects of larval salmon lice stages on wild sea trout Salmo trutta smolts (Tully et al., 1993b; Birkeland, 1996a, b). The hypothesis has been advanced that the larvae on the wild trout had originated from salmon lice on farmed salmon, and consequently, that the salmon farming industry is to blame for the damage to sea trout stocks. This raises the question of how to identify a given louse as originating from a farmed salmon.

Morphometric differences between lice found on wild fish and lice found on farmed fish have been reported (Jackson \& Minchin, 1992; Tully \& Whelan, 1993). Adult female lice from farmed fish are smaller, and have shorter egg strings with fewer eggs than female lice from wild fish (Jackson \& Minchin, 1992; Tully \& Whelan, 1993). These differences may be due to phenotypic plasticity of

* the lice, or may be genetically fixed. In the latter case, the scenario is that frequent chemical treatments would act as a selective agent driving the evolution towards a smaller size and fewer eggs, 
because only the most rapidly developing females would produce any offspring at all (Grimnes et al., 1996; Todd et al., 1997). The results of such a selection will depend on selection pressure and duration, but also on the association and heritability of the traits involved. Molecular biological techniques have been employed to find genetic markers that can identify louse origin, but none has been found so far (Todd et al., 1997). In this paper we test the hypothesis that salmon lice from farmed salmon are smaller than lice from wild fish, by rearing lice of both origins from egg to adult at the same temperature.

\section{Materials and methods}

\section{Sampling}

Salmon lice were collected from wild and farmed salmon as described in Table I.

The farming localities have for two decades been used to raise salmon, and organophosphates have been regularly been used in louse control. Austevoll, which is southwest of Bergen on the Norwegian west coast, has one of Norway's highest densities of salmon farms. Jondal is in the Hardanger Fjord, east of Bergen, which also has a large number of salmon farms.

The wild fish were caught in bag nets and gill nets as described in Table I and Fig. 1. The sampling locations were, with exception of Morvik, distant from salmon farms, which are found inshore in this area. Salmon were also sampled in the Oslo Fjord at Sandvika, $15 \mathrm{~km}$ southwest of Oslo. The nearest salmon farm is more than 100 $\mathrm{km}$ away, downstream in the Norwegian coastal current. Lice were only collected from fish that had no external signs of originating from a farm. Fish that harboured chalimus larvae (i.e. recently infected in the coastal zone) were not sampled to minimize the risk of including lice originating from coastal farms.

Lice and egg strings were transported in seawater in insulated containers to the laboratory at the Department of Biology, University of Oslo. The material from Austevoll held $4-8^{\circ} \mathrm{C}$ on arrival, the other samples held $8-10^{\circ} \mathrm{C}$. Total length, cephalothorax length and greatest width (without the hyaline membrane) were measured. Egg string length was measured, and the number of eggs per string was calculated from the mean length of two randomly chosen 10-egg sections of each string. Measurements were made on live animals with an ocular micrometer at 6 or $8 \times$ (whole animals and egg strings) or 50-80 $\times$ magnification. Total length was from the anterior end of the cephalothorax to the end of the caudal rami, and cephalothorax length from the anterior end of the cephalothorax to the beginning of the fourth thoracic segment. Width was measured on the widest part the cephalothorax, without the hyaline membrane. Laboratoryraised adult females were measured when they had produced their first pair of egg strings. Egg data are presented elsewhere.

\section{Experimental infection of salmon}

The egg strings from the different types of lice were hatched and reared to the infective copepodid stage according to the methods described by Heuch (1995) and Heuch et al. (1995).

The experiments were run between July 1995 and February 1996. The fish were held in $100 \times 100 \times$

Table I. Sampling dates and localities of Lepeophtheirus salmonis included in the study.

\begin{tabular}{lllll}
\hline Type of lice & Date & Origin & Material collected & Name of group \\
\hline Farmed & 01.06 .95 & Austevoll & Adult females and egg strings & Farm la \\
& 11.07 .95 & Austevoll & Adult females and egg strings & Farm 1b \\
& 09.07 .95 & Jondal & Adult females and egg strings & Farm 2 \\
Wild & 09.07 .95 & Morvik, Selste, Sale & Adult females and egg strings & Wild 1a \\
& 22.09 .95 & Sale & Adult females and egg strings & Wild 1b \\
& 13.09 .95 & Sandvika & Adult females & Wild 2a \\
& 28.09 .95 & Sandvika & Adult females and egg strings & Wild 2b \\
\hline
\end{tabular}




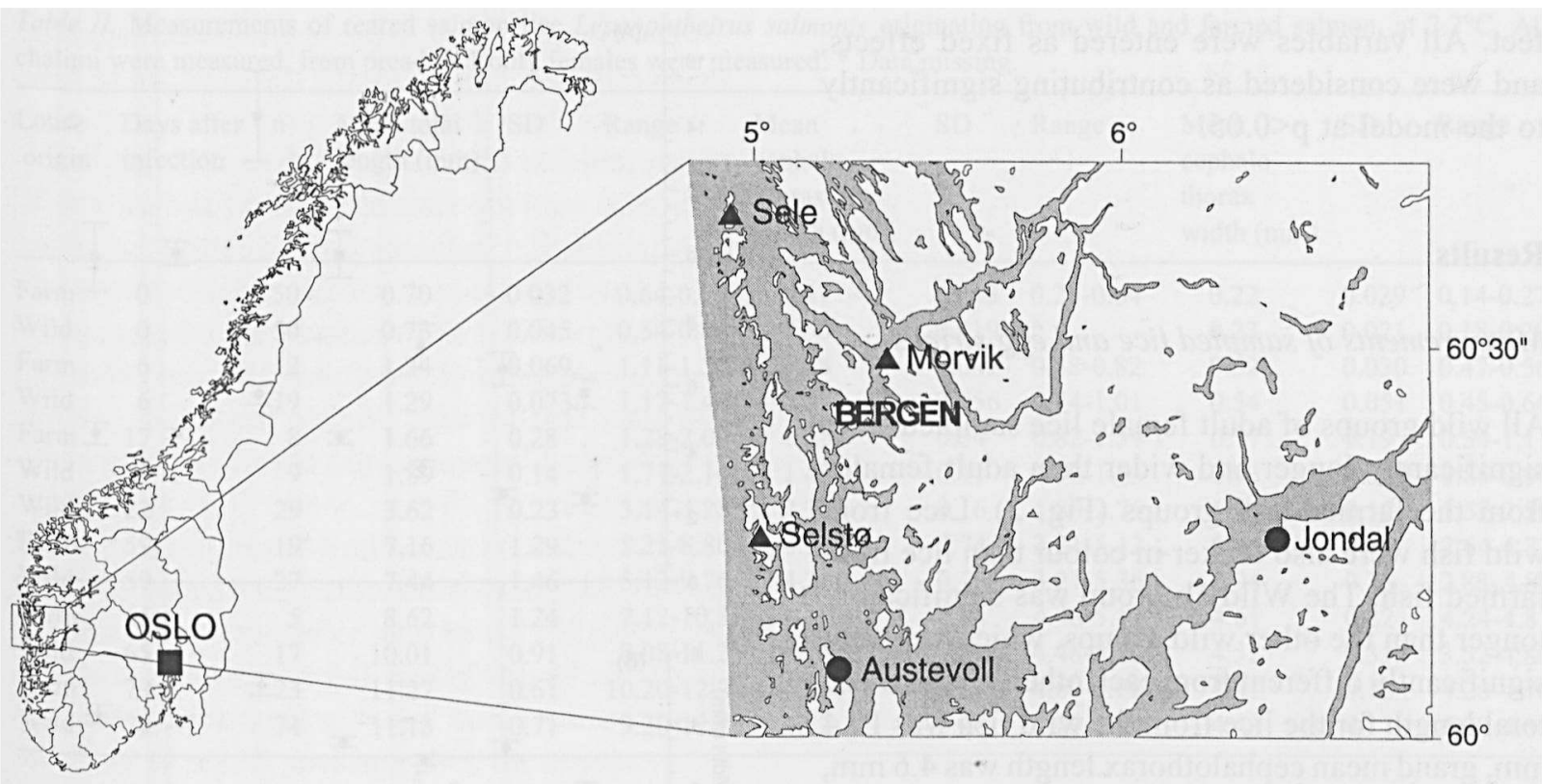

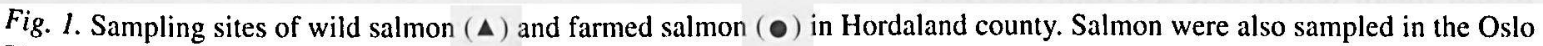
Fjord at Sandvika, $15 \mathrm{~km}$ west of Oslo.

$60 \mathrm{~cm}$ tanks at ambient light conditions at the Norwegian Institute for Water Research's experimental facility at Solbergstrand, just south of Oslo. The fish were of the same family, and of similar age and size (450-510 $\mathrm{g}$ in the equal temperature experiment, and $650-750 \mathrm{~g}$ in the temperature effect experiment).

Initial infection was carried out by lowering the water level to about one-third, and adding approximately 1002 2-5-day old copepodids per fish to each tank. The water was oxygenated by diffusor tubes during this procedure. After four hours the water level was raised to its normal level.

\section{Equal temperature experiment}

Copepodids reared from egg strirgs from Farm $1 \mathrm{~b}$ and Wild la lice were allowed to infect one group of fifteen salmon each, and the growth of the lice was monitored until the first egg strings appeared. The temperature was held at $7.2 \pm 0.4^{\circ} \mathrm{C}$ (SD). One fish was removed from each tank at day $0,6,17$, 29 (Wild la progeny only), 59, 65 and 79 after infection, and killed. All parasites were removed and measured under a binocular low-power microscope.

\section{Temperature effect experiment}

Female size at $8.7 \pm 1.0^{\circ} \mathrm{C}(\mathrm{SD})$ and $12.2 \pm 0.5^{\circ} \mathrm{C}(\mathrm{SD})$ were compared. The copepods (progeny of the Wild la progeny) were raised on two groups of 10 salmon at each temperature. The fish were inspected for presence of females with egg strings every five days without removing them from the water. When more than $50 \%$ of the females had produced one pair of egg strings, the fish were anaesthetized, the lice removed and measured. Only females with egg strings were measured, the reminder were discarded.

\section{Statistics}

Statistics were calculated with SAS 6.12 and JMP 3.6 software. Louse measurements were considered to be normally distributed. Size differences in body proportions and egg strings were examined in $t$-tests and Scheffé's tests with the significance level set at $\alpha=0.05$, and the confidence in"terval at 0.95 . The effect of water temperature on total length, cephalothorax length and width of lice was modelled in SAS" "mixed" procedure. For the louse measurements the models included tank ef- 
fect. All variables were entered as fixed effects, and were considered as contributing significantly to the model at $\mathrm{p}<0.05$.

\section{Results}

\section{Measurements of sampled lice and egg strings}

All wild groups of adult female lice sampled were significantly longer and wider than adult females from the farmed fish groups (Fig. 2). Lice from wild fish were also darker in colour than lice from farmed fish. The Wild $1 \mathrm{~b}$ group was significantly longer than the other wild groups, which were not significantly different from each other. Grand mean total length for the lice from the wild fish was 10.4 $\mathrm{mm}$, grand mean cephalothorax length was $4.6 \mathrm{~mm}$, and grand mean width was $4.0 \mathrm{~mm}(\mathrm{n}=167)$.

The Farm 2 group was significantly longer than Farm $1 \mathrm{a}$ and $1 \mathrm{~b}$, which were not significantly different. The widths of the lice in three farm groups were significantly different. Grand mean length for the lice from the farmed fish was $6.7 \mathrm{~mm}$, grand mean cephalothorax length was $3.0 \mathrm{~mm}$ and grand mean width was $2.9 \mathrm{~mm}(\mathrm{n}=115)$.

There was no significant difference between egg strings from farmed and wild salmon lice. Most strings were about $15 \mathrm{~mm}$ long and contained 100300 eggs. An analysis of egg production in $L$. salmonis is presented elsewhere.

\section{Size and development of progeny of lice from} farmed and wild salmon

Egg strings of Wild 1a and Farm 1b lice were hatched, and the growth of lice followed to production of the first pair of egg strings. All chalimi were included, thereafter, only females were measured.

The growth rates of the two groups were not significantly different (Table II). The adult females were significantly different in length and width, and were both longer and wider than their respective parents (Fig. 3). Whereas Wild 1a lice were darker in colour than Farm $1 \mathrm{~b}$ lice, their progeny had the same colour, resembling that of lice from farmed fish.
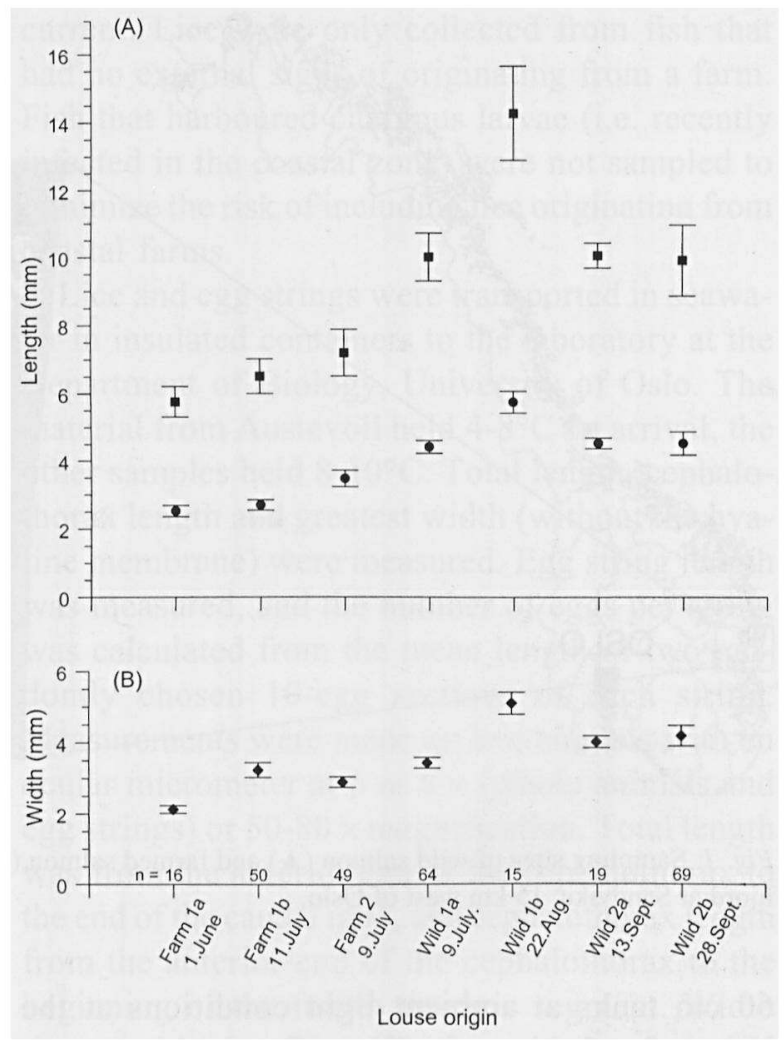

Fig. 2. Average total length ( $\square$ ), cephalothorax length ( $\bullet$ ) and cephalothorax width $(\downarrow) \pm 1$ SD of Lepeophtheirus salmonis females sampled from farmed salmon and wild salmon.

\section{Size of lice reared at different temperatures}

Louse total length, cephalothorax length and width were modelled separately as a function of temperature. Controlling for tank effects, the lice kept at $8.7^{\circ} \mathrm{C}$ had greater total length and cephalothorax length, but a smaller cephalothorax width than those reared at $12.2^{\circ} \mathrm{C}$ (Table III). The small difference in cephalothorax length shows that the increase in total length was mainly due to a longer genital segment (Fig. 4).

\section{Discussion}

As found elsewhere (Tully et al., 1993a; Jackson \& Minchin, 1992), salmon lice collected from wild salmon were longer, wider and darker in colour than salmon lice from farmed fish. If this difference is genetically fixed, the progeny of lice from 
Table II. Measurements of reared salmon lice Lepeophtheirus salmonis originating from wild and farmed salmon, at 7.2 ${ }^{\circ} \mathrm{C}$. All chalimi were measured, from preadult 1 only females were measured. * Data missing.

\begin{tabular}{|c|c|c|c|c|c|c|c|c|c|c|c|}
\hline $\begin{array}{l}\text { Louse } \\
\text { origin }\end{array}$ & $\begin{array}{l}\text { Days after } \\
\text { infection }\end{array}$ & $\mathbf{n}$ & $\begin{array}{l}\text { Mean total } \\
\text { length (mm) }\end{array}$ & SD & Range & $\begin{array}{l}\text { Mean } \\
\text { cephalo- } \\
\text { thorax } \\
\text { length }(\mathrm{mm})\end{array}$ & SD & Range & $\begin{array}{l}\text { Mean } \\
\text { cephalo- } \\
\text { thorax } \\
\text { width }(\mathrm{mm})\end{array}$ & SD & Range \\
\hline Farm & 0 & 50 & 0.70 & 0.032 & $0.64-0.77$ & 0.47 & 0.043 & $0.25-0.64$ & 0.22 & 0.029 & $0.14-0.27$ \\
\hline Wild & 0 & 50 & 0.73 & 0.045 & $0.54-0.80$ & 0.50 & 0.019 & * & 0.23 & 0.021 & $0.18-0.29$ \\
\hline Farm & 6 & 12 & 1.24 & 0.069 & $1.11-1.36$ & 0.78 & 0.042 & $0.68-0.82$ & 0.52 & 0.030 & $0.47-0.56$ \\
\hline Wild & 6 & 19 & 1.29 & 0.073 & $1.17-1.46$ & 0.83 & 0.056 & $0.74-1.01$ & 0.54 & 0.051 & $0.45-0.66$ \\
\hline Farm & 17 & 8 & 1.66 & 0.28 & $1.28-2.00$ & 1.25 & 0.34 & $0.82-1.59$ & 0.77 & 0.19 & $0.54-1.11$ \\
\hline Wild & 17 & 9 & 1.89 & 0.14 & $1.71-2.16$ & 1.43 & 0.11 & $1.30-1.63$ & 0.93 & 0.054 & $0.85-0.99$ \\
\hline Wild & 22 & 29 & 3.62 & 0.23 & $3.14-4.28$ & 2.36 & 0.16 & $1.88-2.75$ & 1.94 & 0.12 & $1.57-2.20$ \\
\hline Farm & 59 & 19 & 7.16 & 1.29 & $5.21-8.80$ & 4.31 & 0.74 & $3.21-5.12$ & 3.86 & 0.82 & $2.64-4.72$ \\
\hline Wild & 59 & 27 & 7.44 & 1.46 & $5.12-9.76$ & 4,28 & 0.79 & $3.21-5.36$ & 3.94 & 0.78 & $2.88-4.88$ \\
\hline Farm & 65 & 5 & 8.62 & 1.24 & $7.12-10.32$ & 4.80 & 0.25 & $4.48-5.12$ & 4.61 & 0.22 & $4.24-4.8$ \\
\hline Wild & 65 & 17 & 10.01 & 0.91 & $8.08-11.2$ & 4.96 & 0.20 & $4.48-5.20$ & 4.52 & 0.33 & $3.52-4.80$ \\
\hline Farm & 79 & 23 & 11.27 & 0.61 & $10.20-12.70$ & 4.86 & 0.17 & $4.60-5.20$ & 4.41 & 0.18 & $4.20-4.70$ \\
\hline Wild & 79 & 71 & 11.13 & 0.71 & $9.20-12.70$ & 4.82 & 0.26 & $4.20-6.00$ & 4,43 & 0.17 & $4.00-4.80$ \\
\hline
\end{tabular}

Table III. Size differences between egg-bearing adult female lice (Lepeophtheirus salmonis) due to temperature, as estimated by a linear regression model while controlling for tank effects. Two parallels were run at each temperature.

\begin{tabular}{lllll}
\hline Rearìing temperature $\left({ }^{\circ} \mathrm{C}\right)$ & $\begin{array}{l}8.7 \pm 1.0 \\
\mathrm{n}=30 \text { and } 5\end{array}$ & $\begin{array}{l}\mathrm{SE} \\
\text { (estimate) }\end{array}$ & $\begin{array}{l}12.2 \pm 0.5 \\
\mathrm{n}=27 \text { and } 19\end{array}$ & $\begin{array}{l}\text { SE } \\
\text { (estimate) }\end{array}$ \\
\hline Total length $(\mathrm{mm})$ & 13.88 & 0.17 & 10.14 & 0.14 \\
Cephalothorax length $(\mathrm{mm})$ & 4.88 & 0.05 & 4.44 & 0.04 \\
Cephalothorax width $(\mathrm{mm})$ & 3.90 & 0.04 & 4.13 & 0.03 \\
\hline
\end{tabular}

wild fish should, all other things being equal, be larger than lice from farmed salmon. The present results showed that the progeny of the lice from the two different host categories were equal in size and colour when reared under similar conditions. We infer that possible genetic differences between the two louse populations are not manifested in louse size or colour, and that the observed differences in collected lice may be due to the lice having experienced different environmental conditions. In the following discussion, the sampled material is compared with other published work on louse morphometry, and the influence of the host on louse size is considered in the light of the experimental results of the present study.

\section{Sampled lice and egg strings}

Mean total length of lice from wild salmon found in the present investigation, $10-14 \mathrm{~mm}$, lies within the size range reported by other authors. In a study from Ireland, adult female lice from wild salmon were found to have a mean total length of 15.2 mm (Jackson \& Minchin, 1992) and total lengths up to $12 \mathrm{~mm}$ have been recorded in Nova Scotia (White, 1940). Adult females from farmed fish have been reported to be 7-14 mm long (Wootten et al., 1982; Tully, 1989; Jackson \& Minchin, 1992; Schram, 1993). Female lice of Canadian origin reared in the laboratory at $10^{\circ} \mathrm{C}$ had a mean total length of $10.0 \mathrm{~mm}$ (Johnson \& Albright, 1991).

The largest (wild) lice found by Tully and Whelan (1993) in Ireland had cephalothorax lengths of 5$5.5 \mathrm{~mm}$, which is comparable to the Wild la sample in the present study. Lice from Scottish farmed salmon showed a seasonal variation in cephalothorax length, with minimum mean value of $4.3 \mathrm{~mm}$ and a maximum mean of $5.0 \mathrm{~mm}$ (Ritchie et al., 1993). These lice are larger than the lice sampled from farmed salmon in the present study, although 


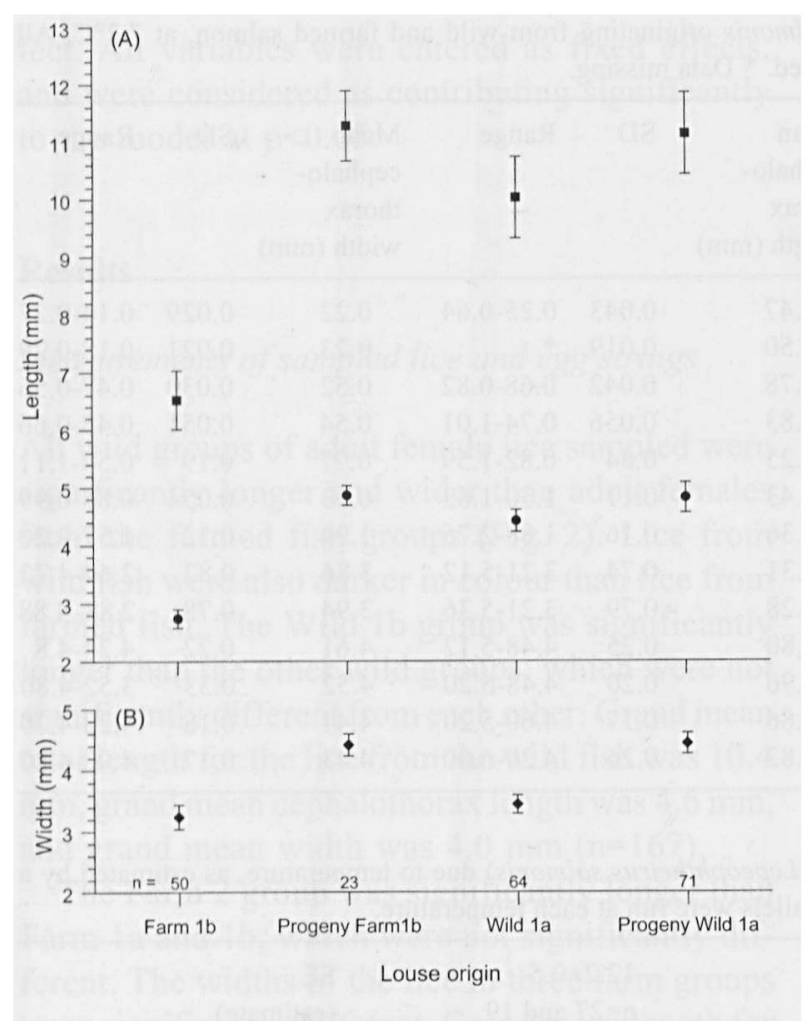

Fig. 3. Average total length ( $(\mathbf{0})$, cephalothorax length $(\bullet)$ and cephalothorax width $(\diamond) \pm 1$ SD of Lepeophtheirus salmonis females from two generations collected from farmed and wild salmon. The progeny were all raised in the laboratory at $7.2^{\circ} \mathrm{C}$.

they were treated monthly with organophosphates. Sharp et al. (1994) measured female lice from sea trout (Salmo trutta L.) sampled in Scottish rivers. Their data showed that mean cephalothorax lengths were highly variable between rivers, from 4.1- 5.6 $\mathrm{mm}$. Farmed lice in the present study had mean cephalothorax lengths of 2.2-3.5 mm, so the Scottish data are closer to the sizes of our samples of wild lice. Thus, there seems to be great variation in louse size both in time and space. For a large part, the variation in total length of female adult lice can be ascribed to different development of the genital complex, which expands both before (Ritchie et al., 1996) and during egg string production (Schram, 1993). The present study shows that the increase in size at $8.7^{\circ} \mathrm{C}$ as compared to $12.2^{\circ} \mathrm{C}$ is largely a consequence of genital complex growth. No information on the degree of development of the genital complex of the sampled lice is available in the previously published nor in the present material, hence the recorded size differences might have been the result of the females having reached different degrees of maturation. Measurements of the cephalothorax would be expected to be less variable, but as shown above, these also differ between farm localities regularly treated with organophosphates, and between rivers (Sharp et al., 1994). Although the lice sampled from farmed salmon in the present study were significantly smaller than the lice from wild salmon, the published louse sizes do not fall into this general pattern.

Other factors, such as host condition and use of growth retarding chemotherapeutants (Tully \& Whelan, 1993) may also influence louse size. In the Pacific Ocean several salmon species may serve as hosts for salmon lice, but they are different in their susceptibility (Nagasawa, 1987; Johnson \& Albright, 1991, 1992; Johnson, 1993; Nagasawa \& Takami, 1993). On less favourable host species sessile stages may be killed, or have a lower growth rate (Johnson \& Albright, 1992; Johnson, 1993) or a lower number of eggs per egg string (Johnson, 1993). Host susceptibility may vary within species as well, either as a function of diet or behaviour, or as a function of genetic differences in resistance to lice (MacKinnon et al., 1995, MacKinnon, 1998). This may explain differences in the size of the sampled lice in the present investigation, even if all the sampled lice originally came from farmed fish.

Direct effects of chemotherapeutants on louse size and fecundity have been suggested as an explanation for the observed differences between lice from farmed and wild fish in Ireland (Tully \& Whelan, 1993). The extent to which the chemicals compromise growth of surviving lice is not known. For the effect to appear in the present sampled material, these lice would have had to have survived at least one chemical treatment during their life time. The farmed fish were treated with organophosphates in the spring or early summer 1995 , so this effect cannot be excluded.

Contrary to other published studies (Jackson \& Minchin, 1992; Tully \& Whelan, 1993), the egg strings from lice from wild fish had a similar average length and number of eggs as those sampled at farms. This may suggest a weaker link between 
female size and length of its egg strings than previously thought, or it may imply that the louse population is more homogenous.

Tully and Whelan (1993) estimated that approximately $95 \%$ of the production of lice larvae in western Ireland originated from farmed salmon. Equivalent estimates do not exist for the Norwegian coast, but the production of salmon here was approximately 15 times the Irish production in 1993 (Anon., 1998). In Norway, the marine salmonid fisheries, including escaped salmon, amounted to 513 tons in 1995 (Anon., 1996), whereas the production of farmed salmon was 263000 tons the same year (Anon., 1998). It is therefore likely that most of the salmon lice on the Norwegian coast originate from farmed fish. This implies that the possibility of sampling "wild" lice even from wild fish is very small, and that the "wild" lice in the present study may have originated from "farmed" larvae although they were significantly larger than the lice sampled in farms. A survival time of 191 days at c. $7^{\circ} \mathrm{C}$ (Nordhagen, 1997), and the negative logarithmic relationship between generation time and temperature (Tully, 1992), indicate the possibility of life spans approaching one year at lower temperatures. Smolts being infected by farmproduced lice on their way to the sea may therefore return with the same lice a year later. This would further reduce the possibility of keeping a genetically distinct wild population of salmon lice. Whatever the origin of the lice sampled from wild fish, this investigation has shown that when raised under the same conditions, lice from the two sources turn out morphometrically the same.

\section{Temperature effects}

Temperature during ontogeny is an important factor influencing the size attained by animals (Atkinson, 1994, 1995). In an extensive review of this relationship in aquatic ectotherms it was found that increased rearing temperature led to decreasing size in $90 \%$ of the studies (Atkinson, 1995). This was also the result of the present investigation, where the females reared at the lower temperature were significantly longer.

Tully (1992) modelled the generation times of salmon lice in Ireland as a function of tempera-

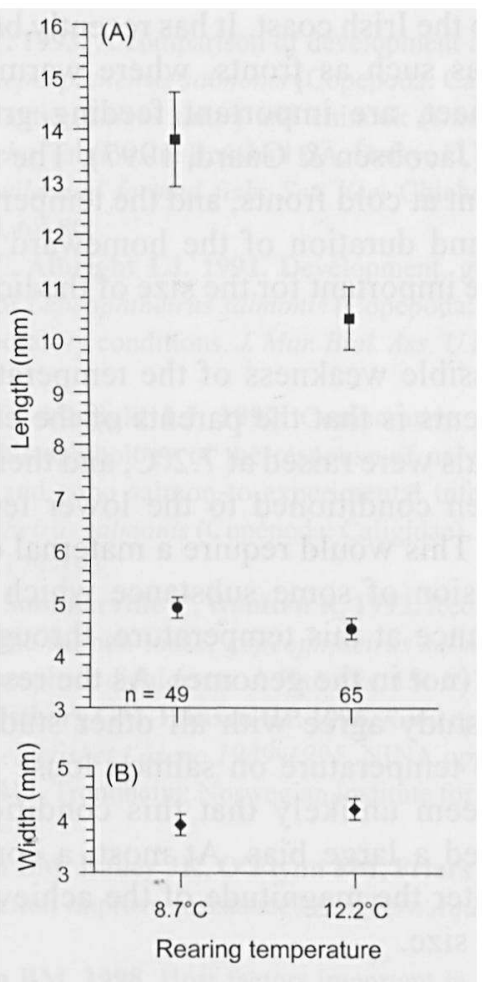

Fig. 4. Average total length ( $\square$ ), cephalothorax length (0) and cephalothorax width $(\diamond) \pm 1$ SD of Lepeophtheirus salmonis females of wild origin raised at $8.7^{\circ} \mathrm{C}$ and $12.2^{\circ} \mathrm{C}$. The two parallels run at each temperature are pooled.

ture, and found that this parameter was a good predictor of population rates in caligid copepods. For salmon lice on farmed salmon in Scotland, Ritchie et al. (1993) found seasonal differences in mean cephalothorax length of adult females with viable egg strings, and suggested these resulted from changing temperature. However, in one of the two farms studied there was a negative correlation with temperature, and in the other a positive correlation. These apparently contradictory results may be a consequence of non-recorded temperature fluctuations at the farm sites, or host-related factors. In an Irish study, Tully and Whelan (1993) argued that differences in salmon louse size and fecundity between samples from wild and farmed salmon could not be explained by temperature, as most Irish farms experience oceanic temperature conditions. However, as salmon lice gen"eration time may approach one year at low temperatures, the salmon hosts could have frequented areas of lower temperature and subsequently mi- 
grated to the Irish coast. It has recently been shown that areas such as fronts, where warm and cold water meet, are important feeding grounds for salmon (Jacobsen \& Gaard, 1997). The amount of time spent at cold fronts, and the temperature conditions and duration of the homeward migration would be important for the size of the lice on these hosts.

A possible weakness of the temperature effect experiments is that the parents of the experimental animals were raised at $7.2^{\circ} \mathrm{C}$, and thereby could have been conditioned to the lower temperature $\left(8.7^{\circ} \mathrm{C}\right)$. This would require a maternal effect, i.e. transmission of some substance which enhances performance at this temperature, through the egg material (not in the genome). As the results of the present study agree with all other studies of the effect of temperature on salmon louse growth, it would seem unlikely that this conditioning has introduced a large bias. At most, a conditioning would alter the magnitude of the achieved differences in size.

\section{Genetic aspects}

The present investigation failed to find phenotypic evidence for genetic differences between salmon lice from wild and farmed fish. Studies of louse morphology (Jackson \& Minchin, 1992, Tully \& Whelan, 1993; Sharp et al., 1994) and molecular biology (Isdal et al., 1997; Todd et al., 1997) suggest a continuous mixing of genes combined with a strong phenotypic plasticity. This would seem reasonable considering the extended (c. 14 days at $10^{\circ} \mathrm{C}$ ) pelagic larval phase (Johannessen, 1978; Johnson \& Albright, 1991) of the parasite, and the instability of the selection pressure for early maturation and smaller size. Maturation at a smaller size most likely has a cost, as female size is correlated with brood size (Tully \& Whelan, 1993). Late-maturing femalês could therefore be favoured, and the selection reversed, when treatment is delayed or is not administered at times of peak abundance of preadult lice. As there is no generally accepted upper limit to lice numbers in a salmon farm, the times at which salmon farmers remove lice vary widely. Mixing of lice larvae from farms with lice from escaped salmon and wild sea trout will also weaken the selection pressure of louse treatments. The amount of escaped salmon in Norwegian coastal waters is unknown, but the available data suggest that approximately $30 \%$ of marine catches are of farm origin (Lund et al., 1996), and that 700000 salmon (Anon., 1998), probably more, escape every year.

Resistance to the organophosphate dichlorvos has been found in salmon lice from Scotland (Jones et al., 1992), indicating that treatments may have genetic consequences for the parasite population. Resistance is often controlled by a single gene (Roush, 1993). In.contrast, life history characters such as growth rates and age at maturation are considered as quantitative traits, controlled by many genes each having a small effect on the organism (Stearns, 1992). Heritability of quantitative traits is typically low (Stearns, 1992), and fixation of alleles may require a continuous strong selection pressure. As this may not be the case for salmon louse age at maturation, the observed size differences would be expected to result from phenotypic plasticity.

\section{Conclusions}

In this study, larvae from lice from wild and farmed salmon, which differed $1.7 \mathrm{~mm}$ in cephalothorax length and $3.5 \mathrm{~mm}$ in total length, were raised on salmon at the same temperature. They had the same growth rate and morphology, and attained the same size at the time they produced their first egg string pair.

If differences in size at time of start of egg production had been genetically fixed as a response to farm practices, this would have produced females of different sizes. This indicates that phenotypic plasticity of the lice is responsible for the size differences observed in the sampled material. Note, however, that this does not exclude the presence of genetic differences between lice populations in other countries. Management practices with respect to the treatment of salmon lice vary because of different availability of drugs, different topography and climate. Long-term use of drugs with a low efficiency against lice in areas with small water exchange, and hence little influx of other sea lice larvae, may possibly create a selection pressure sufficient to give genetically distinct lice. 


\section{Acknowledgements}

We are grateful for the comments and ideas of Chris Appleby, Carey Cunningham, Per J. Jakobsen, Tor Atle Mo and Oliver Tully, which significantly improved the manuscript. Thanks are also due to Karin Boxaspen, Vidar Hjartnes, Morten Merkesdal, Svein Morvik, Ole Leidulf Nordik, and John Erling Sæle for providing lice, and the staff at NIVA Solbergstrand for looking after the fish.

\section{References}

Anonymous. 1996. Lakse- og sjøaurefiske 1993-1995. Report no. C313. (Statistisk Sentralbyrå, Kongsvinger (Statistics Norway)).

Anonymous. 1998. Arsberetning og regnskap 1997. Annual report 1997. Trondheim: Norwegian Fìsh Farmers Association.

Atkinson D. 1994. Temperature and organism size - a biological law for ectoterms? Adv, Ecol. Res. 25: 1-25.

Atkinson D. 1995. Effects of temperature on the size of aquatic ectoterms - exceptions to the general rule. $J$. Therm. Biol. 20: 61-74.

Birkeland K. 1996a. Salmon lice, Lepeophtheirus salmonis Krøyer, infestations and implications for anadromous brown trout, Salmo trutta L. Dr. Sci. thesis. University of Bergen, 1- 20.

Birkeland K. 1996b. Consequences of premature return by sea trout (Salmo trutta) infested with the salmon louse (Lepeophtheirus salmonis): migration, growth, and mortality. Can. J. Fish. Aquat. Sci. 53: 2808-2813.

Grimnes A, Birkeland K, Jakobsen PJ, Finstad B. 1996. Lakselus - nasjonal og internasjonal kunnskapsstatus. NINA Fagrapport no. 18. (NINA - Norwegian Institute for Nature Research, Trondheim), 1-20.

Heuch PA, 1995. Experimental evidence for aggregation of salmon louse copepodids, Lepeophtheirus salmonis, in step salinity gradients. J. Mar, Biol. Ass, U.K. 75: 927-939.

Heuch PA, Parsons A, Boxaspen K. 1995. Diel vertical migration: a possible host-finding mechanism in salmon louse (Lepeophtheinus salmonis) copepodids? Can. J. Fish. Aquat. Sei. 52: 681-689.

Isdal E, Nylund A, Navdal G. 1997. Genetic differences among salmon lice (Lepeophtheirus salmonis) from six Norwegian coastal sites: evidence from allozymes: Bull. Eur. Ass. Fish Pathol. 17: 17-22.

Jackson D, Minchin D. 1992. Aspects of the reproductive output of two calgid copepod species parasitic on cultivated salmon. Invert. Reprod. Dev. 22: 87-90.

Jacobsen JA, Gaard E. 1997. Open-ocean infestation by salmon lice (Lepeophtheirus salmonis); comparison of wild and escaped farmed Atlantic salmon (Salmo salar L.). ICES J. Mar. sci. 54: 1113-1119.

Johannessen A. 1978. Early stages of Lepeophtheirus salmonis (Copepoda, Caligidae). Sarsia 63: 169-176.
Johnson SC. 1993. A comparison of development and growth rates of Lepeophtheirus salmonis (Copepoda: Caligidae) on naive Atlantic (Salmo salar) and chinook (Oncorhynchus tshawytscha) salmon. In: Boxshall GA, Defaye D, eds. Pathogens of wild and farmed fish $\times$ Sea lice. Chichester: Ellis Horwood, 68-80.

Johnson SC, Albright LJ. 1991. Development, growth, and survival of Lepeophtheirus salmonis (Copepoda: Caligidae) under laboratory conditions. J. Mar, Biol. Ass. U,K, 71: 425436.

Johnson SC, Albright LJ. 1992. Comparative susceptibility and histopathology of the response of naive Atlantic, chinook and coho salmon to experimental infection with Lepeophtheirus salmonis (Copepoda: Caligidae), Dis. Aquat. Org. 14: 179-193.

Jones MW, Sommerville C, Wootten R. 1992. Reduced sensitivity of the salmon louse, Lepeophtheirus salmonis to the organophosphate dichlorvos. J. Fish Dis. 15: 197-202.

Lund RA, Østborg GM, Hansen HP. 1996. Rømt oppdrettslaks i sjo- og elvefisket $i$ årene 1989-1995. NINA oppdragsmelding no. 411. Trondheim: Norwegian Institute for Nature Research, 1-16.

MacKinnon BM, Bailey JK, O'Flynn FM, Friars GW. 1995. Can selection improve resistance? Northern Aquaculture 1: 3

MacKinnon BM. 1998. Host factors important in sea lice infections. ICES $J$. Mar. Sci. 55: 188-192.

Nagasawa K. 1987. Prevalence and abundance of Lepeophtheirus salmonis (Copepoda: Caligidae) on high-seas salmon and trout in the North Pacific Ocean. Nippon Suisan Gakkaishi 53: 2151-2156.

Nagasawa K, Takami T. 1993. Host utilisation by the salmon louse Lepeophtheirus salmonis (Copepoda; Caligidae) in the sea of Japan. $J$ Parasitol. 79: 127-130.

Nordhagen JR. 1997. Livshistorie og morfologi til lakselus ( $L e-$ peophtheirus salmonis) fra villaks og oppdrettslaks. University of Oslo, cand. Sci. thesis, 1-51.

Ritchie G, Mordue AJ, Pike AW, Rae H. 1993. The reproductive output of Lepeophtheirus salmonis adult females in relation to seasonal variability of temperature and photoperiod. In: Boxshall GA, Defaye D, eds. Pathogens of wild and farmed fish: Sea Lice. Chichester: Ellis Horwood, 153165.

Ritchie G, Mordue AJ, Pike AW, Rae GH. 1996. Observations on mating and reproductive behaviour in Lepeophtheirus salmonis (Krøyer 1837) (Copepoda: Caligidae), J. Exp. Mar. Biol. Ecol. 201: 285-298.

Roush RT. 1993. Occurrence, genetics and management of insecticíde resístance. Parasitology Today 9: 174-179.

Schram TA. 1993. Supplementary descriptions of the developmental stages of Lepeophtheirus salmonis (Krøyer, 1837) (Copepoda: Caligidae). Inx Boxshall GA, Defaye D, eds. Pathogens of wild and farmed fish: Sea Lice. Chichester: Ellis Horwood, 30-47.

Sharp LA, Pike A, MeVicar AH. 1994. Parameters of infection and morphometric analysis of sea lice from sea trout (Salmo trutta L.) in Scottish waters. In: Pike AW, Lewis JW, 
eds. Parasitic diseases of fish. Tresaith: Samara Publishing, 151-170.

Stearns SC. 1992. The evolution of life histories. Oxford: Oxford University Press, 1-243.

Todd CD, Walker AM, Wolff K, Northeott SJ, Walker AF, Ritchie MG, Hoskins R, Abbott RJ, Hazon N. 1997. Genetic differentiation of populations of the copepod sea louse Lepeophtheirus salmonis (Krøyer) ectoparasitic on wild and farmed salmonids around the coasts of Scotland: Evidence from RAPD markers. J. Exp. Mar, Biol, Ecol, 210: 251274.

Tully 0.1989 . The succession of generations and growth of the caligid copepods Caligus elongatus and Lepeophtheirus salmonis parasitising farmed Atlantic salmon smolts (Salmo salar L.). J. Mar, Biol. Ass. U.K. 69: 279-287.

Tully O. 1992. Predicting infestation parameters and impacts of caligid copepods in wild and cultured fish populations. Inv. Reprod. Dev. 22: 91-102.

Tully O, Poole WR, Whelan KF, 1993a. Infestation parameters for Lepeophtheirus salmonis (Krøyer) (Copepoda: Caligidae) parasitic on sea trout Salmo trutta L., off the west coast of Ireland during 1990 and 1991. Aquacult. Fish. Manage. 24: 545-555.

Tully O, Poole WR, Whelan KF, Merigoux, S. 1993b. Parameters and possible causes of epizootics of Lepeophtheirus salmonis Krøyer infesting sea trout (Salmo trutta $\mathrm{L}_{\text {. }}$ ) off the west coast of Ireland. In* Boxshall GA, Defaye D, eds. Pathogens of wild and farmed fish $\times$ Sea Lice. Chichester: Ellis Horwood, 202-213.

Tully O, Whelan KF. 1993. Production of nauplii of Lepeophtheirus salmonis (Krøyer) (Copepoda: Caligidae) from farmed and wild salmon and its relation to the infestation of wild sea trout (Salmo trutta L.) off the west coast of Ireland in 1991. Fish. Res. 17: 187-200.

White HC. 1940. "Sea lice" and the death of salmon. J. Fish. Res. Board Can. 5: 172-175.

Wootten R. Smith JW, Needham EA. 1982. Aspects of the biology of the parasitic copepods Lepeophtheirus salmonis and Caligus elongatus on farmed salmonids, and their treatment. Proc. $R$. Soc. Edinburgh 81B: 185-197.

Received: 1 February 1999 